\title{
Characteristics and risk factors of tobacco consumption among University of Sharjah students, 2005
}

\author{
A. Mandil, ${ }^{1}$ A. Hussein, ${ }^{2}$ H. Omer, ${ }^{2}$ G. Turki ${ }^{3}$ and I. Gaber ${ }^{3}$
}

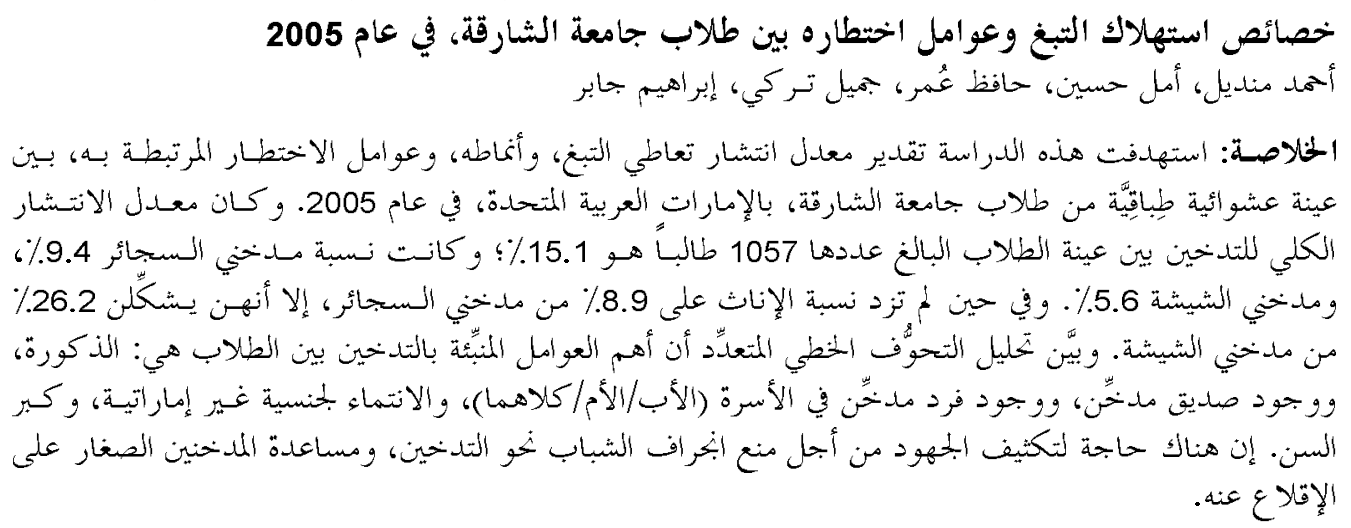

ABSTRACT This study aimed to estimate the prevalence, patterns and risk factors of tobacco consumption among a stratified random sample of students at University of Sharjah, United Arab Emirates (UAE), during 2005. The overall reported smoking prevalence among 1057 sampled students was $15.1 \%$; cigarette smokers were $9.4 \%$ and waterpipe smokers $5.6 \%$. While women comprised only $8.9 \%$ of cigarette smokers, they were $26.2 \%$ of waterpipe smokers. Multiple linear regression analysis showed that the most important predictors for smoking among the students were: male sex, having a smoking friend, having a smoking family member (father/mother/both), non-UAE nationality and older age. There is a need to intensify efforts to prevent young people from starting smoking and to help young smokers to stop.

\begin{abstract}
Caractéristiques et facteurs de risque du tabagisme en 2005 chez les étudiants de l'Université de Sharjah

RÉSUMÉ La présente étude avait pour objectif d'évaluer la prévalence, le profil et les facteurs de risque du tabagisme dans un échantillon aléatoire stratifié d'étudiants de l'Université de Sharjah, aux Émirats arabes unis, au cours de l'année 2005. Sur cet échantillon de 1057 étudiants, la prévalence globale du tabagisme s'élevait à $15,1 \%$, les fumeurs de cigarette représentant $9,4 \%$ et les fumeurs de pipe à eau $5,6 \%$. Tandis que seules $8,9 \%$ des femmes fumaient des cigarettes, $26,2 \%$ s'avouaient utilisatrices de pipe à eau (ou narguilé). Selon l'analyse de régression multiple, les principaux indicateurs du tabagisme estudiantin sont l'appartenance au sexe masculin, l'imitation d'un ami ou d'un membre de la famille (père, mère, voire les deux) eux-mêmes fumeurs, une nationalité étrangère aux Émirats arabes unis et un âge plus avancé. II faudrait intensifier les efforts visant à empêcher les jeunes de commencer à fumer et à aider les jeunes fumeurs à arrêter.
\end{abstract}

${ }^{1}$ High Institute of Public Health, University of Alexandria, Alexandria, Egypt (Correspondence to A. Mandil: ahmedmandil@hotmail.com).

${ }^{2}$ College of Health Sciences, University of Sharjah, United Arab Emirates.

${ }^{3}$ Sharjah Medical District, Sharjah, United Arab Emirates.

المجلة الصحية لشرق المتو سط، منظمة الصحة العالمية، المجلد الثالث عشر، العلد ب، V... 


\section{Introduction}

Tobacco use is one of the chief preventable risk factors of some 25 noncommunicable diseases, many of which are eventually fatal. The World Health Organization (WHO) attributes some 4 million deaths annually to tobacco consumption, and this is expected to rise to 8.4 million by 2020 [1-3]. A report by WHO Regional Office for the Eastern Mediterranean indicates that the prevalence of tobacco consumption among adult males in the countries of the Eastern Mediterranean Region (EMR) ranges from $24 \%$ to $70 \%$ among adult males and $3 \%$ to $22 \%$ among adult females, and that these are among the highest in the world, especially for males [4].

A few studies have estimated tobacco prevalence among young people aged less than 18 years of age in the United Arab Emirates (UAE). The UAE has recently participated in the Global Youth Tobacco Survey (GYTS) which reported that among 4178 surveyed schoolchildren aged 13-15 years, $14.3 \%$ of boys and $2.9 \%$ of girls were current smokers, while $25 \%$ of students had first tried smoking at under 10 years of age, more than $70 \%$ had seen a tobacco advertisement, $20 \%$ had been offered free cigarettes from a tobacco company representative and $50 \%$ had bought their cigarettes from stores, $80 \%$ of whom were not refused purchase because of their age [5]. Another study by the UAE University in 1999 found that 30\% of surveyed 15-19-year-old schoolboys were smokers [6]. A family health survey in 1995 , covering 45830 UAE citizens, revealed that $18.3 \%$ of adult males and $0.4 \%$ of adult females were current smokers [7].

Other studies on tobacco use and its risk factors among secondary-school students were carried out in other Gulf nations, including Bahrain [8], Saudi Arabia [9-12], Kuwait [13] and Yemen [14], and can be compared with high-school students in Belfast [15], Syria [16] and Egypt [17].

In spite of the many studies carried out in the EMR on tobacco consumption among secondary/high-school students, only a few have focused on university students, such as studies performed in Saudi Arabia [18], Jordan [19], Egypt [20], Lebanon [21] and Bahrain [22]. Hence, there was a great need to bridge the gap in the literature for UAE students. This study aimed to estimate the prevalence, patterns and risk factors of tobacco consumption among students attending the University of Sharjah (UoS).

\section{Methods}

The study was cross-sectional, conducted during the academic year 2004/05.

\section{Setting}

Founded in 1997, the UoS is one of the leading higher education establishments in the UAE, with 4 health-related colleges, namely: health sciences, medicine, pharmacy and dentistry, with an overall student population of about 6000 , of whom $66 \%$ (3755) are females, and 34\% (1949) males, with $9.4 \%$ health-related students in 4 colleges (2004/05 data).

\section{Sample}

A stratified proportionate random sampling technique was used to select 1290 students for the study, representing the 13 different colleges of the UoS. The sample size estimate was based on an estimated $20 \%$ prevalence of smoking. Table 1 shows the distribution of the 1290 students in the survey by college.

\section{Questionnaire}

The data collection tool used in the study was a modified version of the standard WHO questionnaire and the GYTS ques- 


\begin{tabular}{|c|c|c|c|}
\hline$\overline{\text { College }}$ & $\begin{array}{c}\text { Total no. } \\
\text { of students }\end{array}$ & $\%$ & $\begin{array}{c}\text { No. } \\
\text { selected }\end{array}$ \\
\hline Arts and sciences & 751 & 13.2 & 170 \\
\hline Business and management & 897 & 15.7 & 200 \\
\hline Communication & 588 & 10.3 & 130 \\
\hline Health and medical sciences ${ }^{a}$ & 535 & 9.4 & 120 \\
\hline Intensive English programme & 701 & 12.3 & 160 \\
\hline Engineering & 660 & 11.6 & 150 \\
\hline Fine arts & 49 & 0.9 & 20 \\
\hline Law & 675 & 11.9 & 150 \\
\hline Sharia and Islamic studies & 438 & 7.7 & 100 \\
\hline Career development & 397 & 7.0 & 90 \\
\hline Total & 5691 & 100.0 & 1290 \\
\hline
\end{tabular}

tionnaires, which have previously been validated for use in both their English and Arabic versions $[23,24]$. It was developed as an anonymous self-administered questionnaire by the investigators (all bilingual), revised, piloted and edited several times before it was finally utilized in its English and Arabic versions.

The study proposal and instrument were approved by the College of Health Sciences Institutional Review Board.

The questionnaire enquired about demographic information (age, sex, marital status, nationality, field of study, residence, work status, pocket money, mother's and father's education, years in university) and tobacco consumption (status, type, frequency, duration, age at first attempt, family members' and peers' smoking status, etc.).

Five data collectors ( 3 women and 2 men), with a social sciences background and experience in supervising student activities in UoS and carrying out surveys among university students were trained by the investigators on how to administer the study tool. To facilitate data collection, the purpose and operation of the study were adequately explained to the deans of students' affairs (men and women) as well as the deans of different UoS colleges in personal letters from the principal investigator. Deans then asked their faculty to cooperate in data collection before/after lectures. The data collectors explained the purpose of the study to the students, asking for their verbal consent, and emphasized the voluntary and anonymous nature of the study.

\section{Statistical analysis}

Data were coded, entered, cleaned and analysed using SPSS, version 14.0. Analysis included univariate, bivariate as well as multivariate analytical techniques. This included calculation of odds ratios (OR) with $95 \%$ confidence intervals $(\mathrm{CI})$ and corresponding $P$-values, while multiple logistic regression was carried out to identify variables most predictive of taking up the habit of smoking among the surveyed

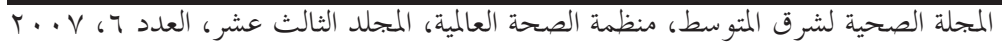


students. $P<0.05$ was used as the level of significance.

\section{Results}

Table 2 shows the characteristics of the study population. The total sample was 1057 students, with a response rate of $82 \%$. The age range was $17-37$ years, mean 20.9 [standard deviation (SD) 2.6] years. About two-thirds of participants in the survey were females $(60.7 \%)$, more than half were UAE nationals (57.2\%) and lived with their parents (53.9\%). Most students were single $(87.9 \%)$ and were from colleges other than health and medical sciences $(84.0 \%)$. About two-thirds of students $(63.1 \%)$ in the sample were in their junior (3rd) or senior (4th) years. More of the students' fathers had university or higher education (44.5\%) than did the mothers (27.3\%).

A total of 163 students reported smoking, giving an overall smoking prevalence (cigarettes and waterpipe) of $15.1 \%$; this was $33.0 \%$ among males, $3.9 \%$ among females (Table 3). The mean age of smokers was 22.3 (SD 2.9) years, slightly older than the whole sample. Smokers in the sample were mostly single $(81.0 \%)$, males $(84.6 \%)$, non-UAE nationals $(62.7 \%)$, nonhealth majors $(89.3 \%)$ and living with their parents or relatives $(64.5 \%)$. Table 3 shows the characteristics of the student smokers, comparing cigarette smokers (prevalence of $9.4 \%)$ with waterpipe smokers $(5.6 \%)$. While most smokers had 1 or more friends who smoked $(86.7 \%)$, less than one-quarter $(24.5 \%)$ had fathers who smoked.

\section{Bivariate analyses}

The results of bivariate analyses showed that the most important predictors of smoking among UoS students in our sample were: male sex $(\mathrm{OR}=12.2$; CI: 7.8-19.0), having a smoking friend $(\mathrm{OR}=9.8$; $\mathrm{CI}: 6.1-15.8)$,

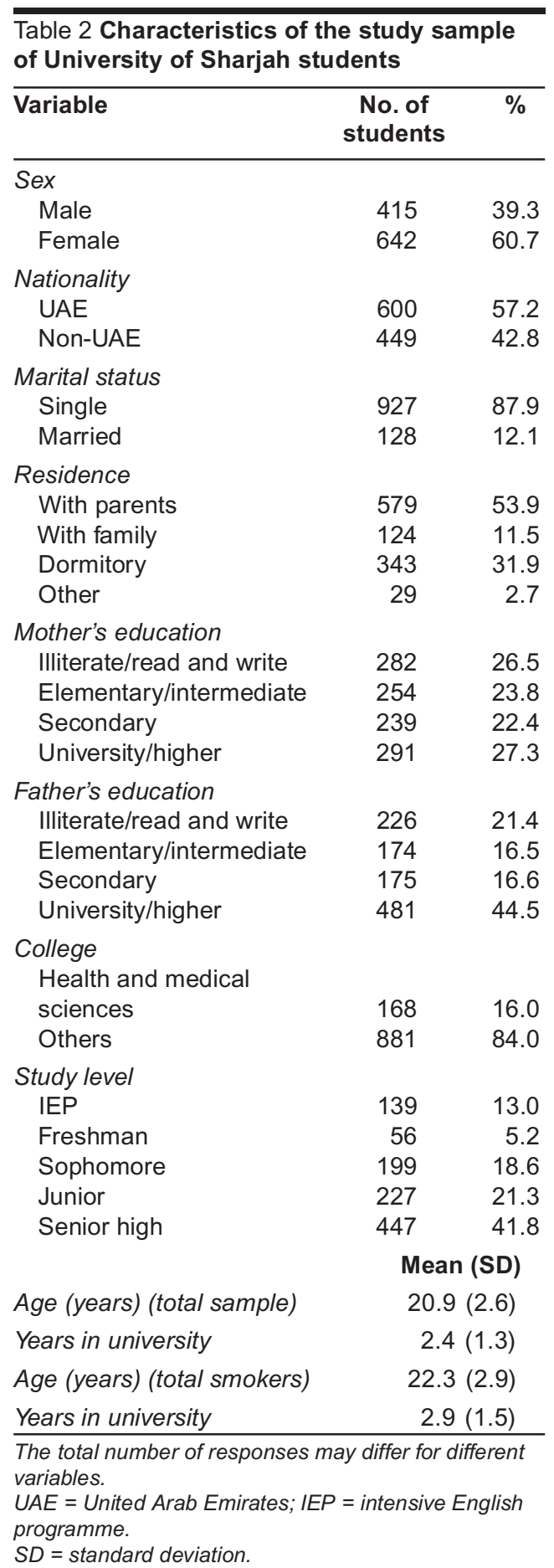


Table 3 Characteristics of reported smokers among University of Sharjah students

\begin{tabular}{|c|c|c|c|c|c|c|}
\hline \multirow[t]{2}{*}{ Variable } & \multicolumn{2}{|c|}{$\begin{array}{l}\text { Cigarette } \\
\text { smokers }\end{array}$} & \multicolumn{2}{|c|}{$\begin{array}{c}\text { Waterpipe } \\
\text { smokers }\end{array}$} & \multicolumn{2}{|c|}{$\begin{array}{c}\text { Total } \\
\text { smokers }\end{array}$} \\
\hline & No. & $\%$ & No. & $\%$ & No. & $\%$ \\
\hline Total sample (prevalence) & 102 & 9.4 & 61 & 5.6 & 163 & 15.1 \\
\hline \multicolumn{7}{|l|}{ Sex } \\
\hline Male & 92 & 91.1 & 45 & 73.8 & 137 & 84.6 \\
\hline Female & 9 & 8.9 & 16 & 26.2 & 25 & 15.4 \\
\hline \multicolumn{7}{|l|}{ Nationality } \\
\hline UAE & 37 & 37.8 & 22 & 36.7 & 59 & 37.3 \\
\hline Non-UAE & 61 & 62.2 & 38 & 63.3 & 99 & 62.7 \\
\hline \multicolumn{7}{|l|}{ Marital status } \\
\hline Single & 84 & 84.8 & 45 & 73.8 & 129 & 80.6 \\
\hline Married & 15 & 15.2 & 16 & 26.2 & 31 & 19.4 \\
\hline \multicolumn{7}{|l|}{ Residence } \\
\hline With parents & 51 & 50.0 & 28 & 45.9 & 79 & 48.5 \\
\hline With family & 16 & 15.7 & 10 & 16.4 & 26 & 16.0 \\
\hline Dormitory & 28 & 27.5 & 20 & 32.8 & 48 & 29.4 \\
\hline Other & 7 & 6.9 & 3 & 4.9 & 10 & 6.1 \\
\hline \multicolumn{7}{|l|}{ Mother's education } \\
\hline Illiterate/read and write & 25 & 24.8 & 4 & 6.6 & 29 & 17.9 \\
\hline Elementary/intermediate & 11 & 10.9 & 16 & 26.2 & 27 & 16.7 \\
\hline Secondary & 23 & 22.8 & 14 & 23.0 & 37 & 22. \\
\hline University/higher & 42 & 41.6 & 27 & 44.3 & 69 & 42.6 \\
\hline \multicolumn{7}{|l|}{ Father's education } \\
\hline Illiterate/read and write & 22 & 22.0 & 9 & 14.8 & 31 & 19.3 \\
\hline Elementary/intermediate & 8 & 8.0 & 5 & 8.2 & 13 & 8.1 \\
\hline Secondary & 12 & 12.0 & 16 & 26.2 & 28 & 17.4 \\
\hline University/higher & 58 & 58.0 & 31 & 50.8 & 89 & 55.3 \\
\hline \multicolumn{7}{|l|}{ College } \\
\hline Health and medical sciences & 10 & 10.2 & 7 & 11.5 & 17 & 10.7 \\
\hline Other & 88 & 89.8 & 54 & 88.5 & 142 & 89.3 \\
\hline \multicolumn{7}{|l|}{ Study level } \\
\hline IEP & 3 & 3.0 & 3 & 5.1 & 6 & 3.8 \\
\hline Freshman & 5 & 5.0 & 3 & 5.1 & 8 & 5.0 \\
\hline Sophomore & 23 & 23.0 & 9 & 15.3 & 32 & 20.1 \\
\hline Junior & 21 & 21.0 & 6 & 10.2 & 27 & 17.0 \\
\hline Senior high & 48 & 48.0 & 38 & 64.4 & 86 & 54.0 \\
\hline \multicolumn{7}{|l|}{ Smoking status of parents } \\
\hline Father only & 22 & 23.2 & 16 & 26.7 & 38 & 24.5 \\
\hline Mother only & 1 & 1.1 & 2 & 3.3 & 3 & 1.9 \\
\hline Both parents & 3 & 3.2 & 5 & 8.3 & 8 & 5.2 \\
\hline None & 44 & 46.3 & 22 & 36.7 & 66 & 42.6 \\
\hline
\end{tabular}

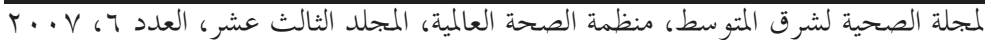




\begin{tabular}{|c|c|c|c|c|c|c|}
\hline \multirow[t]{2}{*}{ Variable } & \multicolumn{2}{|c|}{$\begin{array}{l}\text { Cigarette } \\
\text { smokers }\end{array}$} & \multicolumn{2}{|c|}{$\begin{array}{c}\text { Waterpipe } \\
\text { smokers }\end{array}$} & \multicolumn{2}{|c|}{$\begin{array}{c}\text { Total } \\
\text { smokers }\end{array}$} \\
\hline & No. & $\%$ & No. & $\%$ & No. & $\%$ \\
\hline \multicolumn{7}{|l|}{ Smoking status of friends } \\
\hline None & 11 & 11.1 & 10 & 16.9 & 21 & 13.3 \\
\hline Some/most of them & 77 & 77.7 & 40 & 67.8 & 117 & 74.0 \\
\hline All of them & 11 & 11.1 & 9 & 15.3 & 20 & 12.7 \\
\hline
\end{tabular}

working $(\mathrm{OR}=4.0$; $\mathrm{CI}: 2.6-6.2)$, non-UAE nationality $(\mathrm{OR}=2.6$; $\mathrm{CI}$ : $1.8-3.7)$, higher education of father $(\mathrm{OR}=2.1$; CI: $1.5-3.0)$, having pocket money of $>500$ Arab Emirate dirhams $(\mathrm{OR}=2$; CI: 1.4-2.9), single status $(\mathrm{OR}=1.95 ; \mathrm{CI}: 1.25-3.0)$, having a smoking family member (father/mother/ both) $(\mathrm{OR}=1.9$; $\mathrm{CI}: 1.3-2.8)$, and mother's education $(\mathrm{OR}=1.76$; CI: 1.2-2.6) (Table 4).

\section{Multiple logistic regression analyses}

Results of multiple logistic regression analysis showed that the most important predictors for smoking among students in our sample were: male sex $(\mathrm{OR}=6.1$; $\mathrm{CI}$ : $3.2-11.7)$, having a smoking friend $(\mathrm{OR}=$ 3.3; CI: 1.7-6.4), having a smoking family member (father/mother/both) $(\mathrm{OR}=2.1$; CI: $1.2-3.5)$ and older age group $(\mathrm{OR}=1.2$; CI: 1.0-1.3) (Table 5).

\section{Discussion}

The UAE Ministry of Health (MoH) has been implementing important measures to combat smoking, whether through antismoking campaigns with special emphasis on primary prevention of smoking among adolescents, or establishment of antismoking clinics during the past 8 years across the 9 districts of the $\mathrm{MoH}$ in the 7 Emirates [25].
Nevertheless, smoking still remains prevalent among young people in the UAE. This study showed that $15.1 \%$ of surveyed students reported smoking, with a much higher prevalence among males $(33.0 \%)$ than females $(3.9 \%)$. Such figures seem to be comparable to other studies in the EMR among university students [18-22] or high-school students [8-17]. The smoking prevalence ranged from $11.8 \%$ among Cairo University students, Egypt [20] (22\% among males; $1.7 \%$ among females) and $28.6 \%$ among Jordan University of Science and Technology students [19] (50\% among males; $6.5 \%$ among females). A study of Aga Khan University medical students, Pakistan [26], also reported a considerable sex difference (17\% among males; $4 \%$ among females). Reported figures among high-school males in the EMR ranged from $16 \%$ to $22 \%$ in different studies $[6,8,11,12,14,16]$.

The gender difference is explainable, given the local traditions in the EMR, but it should be noted that figures here are reported ones, and females, despite the anonymity of the questionnaire, are less likely to report a habit which may be seen as a "social stigma". It has also been observed that smoking prevalence is on the rise among women in the EMR in recent years, especially waterpipe consumption [personal 
\begin{tabular}{ll}
\hline Eastern Mediterranean Health Journal, Vol. 13, No. 6, 2007 & 1455
\end{tabular}

Table 4 Results of bivariate analysis of risk factors for tobacco consumption among University of Sharjah students

\begin{tabular}{|c|c|c|c|c|c|c|c|}
\hline \multirow[t]{2}{*}{ Variable } & \multicolumn{2}{|c|}{ Smoker } & \multicolumn{2}{|c|}{ Non-smoker } & \multirow{2}{*}{$\begin{array}{l}\text { Odds } \\
\text { ratio }\end{array}$} & \multirow[t]{2}{*}{$95 \% \mathrm{Cl}$} & \multirow[t]{2}{*}{$P$-value } \\
\hline & No. & $\%$ & No. & $\%$ & & & \\
\hline \multicolumn{8}{|l|}{ Sex } \\
\hline Male & 137 & 32.8 & 281 & 67.2 & 12.20 & $7.8-19.0$ & 0.001 \\
\hline Female & 25 & 3.9 & 623 & 96.1 & & & \\
\hline \multicolumn{8}{|l|}{ Marital status } \\
\hline Single & 129 & 13.8 & 805 & 86.2 & 1.95 & $1.25-3.05$ & 0.006 \\
\hline Married & 31 & 23.8 & 99 & 76.2 & & & \\
\hline \multicolumn{8}{|l|}{ Residence } \\
\hline Dormitory & 48 & 14.0 & 295 & 86.0 & 1.15 & $0.80-1.65$ & 0.523 \\
\hline Other & 115 & 15.7 & 617 & 84.3 & & & \\
\hline \multicolumn{8}{|l|}{ College } \\
\hline Health and medical sciences & 17 & 10.1 & 151 & 89.9 & 1.71 & $1.0-2.91$ & 0.046 \\
\hline Other & 142 & 16.1 & 739 & 83.9 & & & \\
\hline \multicolumn{8}{|l|}{ Employed } \\
\hline Yes & 41 & 36.3 & 72 & 63.7 & 4.05 & $2.63-6.22$ & 0.001 \\
\hline No & 115 & 12.3 & 817 & 87.7 & & & \\
\hline \multicolumn{8}{|l|}{ Pocket money (AED) } \\
\hline$<500$ & 45 & 10.4 & 389 & 89.6 & 2.02 & $1.40-2.93$ & 0.001 \\
\hline $500+$ & 113 & 19.0 & 483 & 81.0 & & & \\
\hline \multicolumn{8}{|l|}{ A family member smokes } \\
\hline Yes & 49 & 22.4 & 170 & 77.6 & 1.90 & $1.3-2.77$ & 0.001 \\
\hline No & 106 & 13.2 & 697 & 86.8 & & & \\
\hline \multicolumn{8}{|l|}{ A friend smokes } \\
\hline Yes & 137 & 28.1 & 351 & 71.9 & 9.78 & $6.06-15.78$ & 0.001 \\
\hline No & 21 & 3.8 & 526 & 96.2 & & & \\
\hline \multicolumn{8}{|l|}{ Study level } \\
\hline Junior and senior & 113 & 16.8 & 561 & 83.2 & 1.52 & $1.06-2.20$ & 0.026 \\
\hline Other & 46 & 11.7 & 348 & 88.3 & & & \\
\hline \multicolumn{8}{|l|}{ Mother's education } \\
\hline Secondary or more & 106 & 20.0 & 424 & 80.0 & 2.14 & $1.51-3.04$ & \\
\hline$<$ Secondary & 56 & 10.4 & 480 & 89.6 & & & 0.001 \\
\hline \multicolumn{8}{|l|}{ Father's education } \\
\hline Secondary or more & 117 & 17.8 & 539 & 82.2 & 1.76 & $1.21-2.55$ & 0.003 \\
\hline$<$ Secondary & 44 & 11.0 & 356 & 89.0 & & & \\
\hline \multicolumn{8}{|l|}{ Nationality } \\
\hline UAE & 59 & 9.7 & 547 & 90.3 & 2.60 & $1.83-3.69$ & 0.001 \\
\hline Other & 99 & 21.9 & 353 & 78.1 & & & \\
\hline \multicolumn{8}{|l|}{ Age (years) } \\
\hline$<20$ & 111 & 21.7 & 401 & 78.3 & 2.69 & $1.88-3.83$ & 0.001 \\
\hline $20+$ & 50 & 9.3 & 486 & 90.7 & & & \\
\hline \multicolumn{8}{|l|}{ Years in university } \\
\hline$\leq 2$ & 67 & 11.4 & 519 & 88.6 & 1.79 & $1.27-2.55$ & 0.001 \\
\hline$>2$ & 82 & 18.8 & 354 & 81.2 & & & \\
\hline
\end{tabular}

The total number of responses may differ for different variables.

$\mathrm{Cl}=$ confidence interval; $U A E=$ United Arab Emirates; $A E D=$ Arab Emirates dirham .

المجلة الصحية لشرق المتوسط، منظمة الصحة العالمية، المجلد الثالث عشر، العدد ج، V... 
observation]. In our study, it was shown that while only $8.9 \%$ of cigarette smokers in our study were females, $26.2 \%$ of reported waterpipe smokers were females.

Being a male with a smoking friend or family member was shown by multiple regression analysis in our study to be the most predictive factor for being a smoker. In fact, having a smoking friend (peer pressure) has been shown by this study and many others to be consistently linked with smoking of youngsters. A Bahraini study reported that $43 \%$ of smokers reported that their best friend was a smoker, compared with $15.4 \%$ among non-smokers [19]. Similar results were reported from other Gulf country studies in Saudi Arabia [9,10], Kuwait [13] and Yemen [14].

\section{Conclusion and Recommendations}

We conclude, based on the findings in this study, that an intensification of efforts is needed to prevent young people taking up the habit of smoking and to help those who consume tobacco to swiftly quit before serious complications ensue. Both cigarettes and the waterpipe still attract young people, including females, not only in the UAE, but also in many other countries of the EMR. In fact, one-third of the smokers in our study were waterpipe smokers, and it was the most common habit among female smokers. This points to the need for effective outreach health education programmes, targeting young schoolchildren, in primary education, before they take up the habit of smoking. Teachers and parents should be involved, and the mass and mini media all brought into action.

The message emerging from the role of peer pressure in smoking is for role models in the community, for example parents, teachers (in basic and university education), community and religious leaders. The health community is no exception here, and there is no value of preaching the harmful effects of smoking and asking the public to avoid or quit the habit, when many health professionals themselves are smokers. We are a long way from reducing the incidence as well prevalence of tobacco consumption among students, but combined multisectoral efforts are called for without delay.

\begin{tabular}{|c|c|c|c|c|c|}
\hline Variable & $\begin{array}{c}\boldsymbol{\beta} \\
\text { coefficient }\end{array}$ & SE (B) & $\begin{array}{l}\text { Odds } \\
\text { ratio }\end{array}$ & $95 \% \mathrm{Cl}$ & $P$-value \\
\hline A friend smokes ${ }^{a}$ & 1.20 & 0.34 & 3.31 & $1.71-6.42$ & 0.001 \\
\hline $\begin{array}{l}\text { A family member } \\
\text { smokes }^{a}\end{array}$ & 0.73 & 0.26 & 2.07 & $1.24-3.47$ & 0.006 \\
\hline $\mathrm{Age}^{\mathrm{b}}$ & 0.14 & 0.06 & 1.15 & $1.03-1.29$ & 0.016 \\
\hline $\mathrm{Sex}^{\mathrm{c}}$ & 1.81 & 0.33 & 6.13 & $3.21-11.69$ & 0.001 \\
\hline Constant & -8.02 & 1.21 & - & - & 0.001 \\
\hline
\end{tabular}

aNone is reference; ${ }^{b}$ continuous; ${ }^{c}$ female is reference.

$\mathrm{Cl}=$ confidence interval; $\mathrm{SE}=$ standard error . 


\section{References}

1. World no tobacco day 2005. Geneva, World Health Organization, 2005

2. The health consequences of smokingnicotine addiction. A report of the Surgeon General. Atlanta, Georgia, Centers for Disease Control, 1988.

3. Curbing the epidemic. Governments and the economics of tobacco control. Washington DC, World Bank, 1999.

4. Tobacco control country profiles for the Eastern Mediterranean Region. Cairo, World Health Organization, Regional Office for the Eastern Mediterranean, 2003.

5. Fikri M, Abi-Saab BH. Global youth tobacco survey. UAE Report. Abu Dhabi, UAE, Central Health Education Department, Preventive Medicine Sector, 2002.

6. Bener A, Al-Ketbi LM. Cigarette smoking habits among high school boys in a developing country. Journal of the Royal Society of Health, 1999; 119(3):166-9.

7. Fikri M. United Arab Emirates family health survey (part of Gulf family health survey). Riyadh, Gulf Cooperation Council, Council of Health Ministers, Executive Board 1995:77-81.

8. Al-Haddad N, Hamadeh RR. Smoking among secondary school boys in Bahrain: prevalence and risk factors. Eastern Mediterranean health journal, 2003 9(1/2):91-4.

9. Felimban FM, Jarallah. Smoking habits of secondary school boys in Riyadh, Saudi Arabia. Saudi medical journal, 1994 15:438-92.

10. Jarallah JS etal. Predictors of smoking among male junior secondary school students in Riyadh, Saudi Arabia. Tobacco control, 1996, 5:26-9.

11. Al-Faris EA. Smoking habits of secondary school boys in rural Riyadh. Public health, 1995, 109(1):47-55
12. Al-Yousef MA. Prevalence of smoking among high school students. Saudi medical journal, 2001, 22(10):872-4.

13. Moody PM. Factors associated with the initiation of smoking by Kuwaiti males. Journal of substance abuse, 1998, 10(4):375-84.

14. Bawazeer AA, Hattab AS, Morales E. First cigarette smoking experience among secondary school students in Aden, Republic of Yemen. Eastern Mediterranean health journal, 1999, 5:440-9.

15. Almas $\mathrm{K}$ et al. Smoking behavior and knowledge in high school students in Riyadh and Belfast. Odonto-stomatologie tropicale, 2002, 25:40-4

16. Maziak W, Mzayek F. Characterization of the smoking habit among high school students in Syria. European journal of epidemiology, 2000, 16(12):1169-72.

17. Gadallah $S$ et al. Prevalence of smoking among secondary school students in Qualyobia Governorate. Journal of the Egyptian Society of Parasitology, 2003, 33:1031-50.

18. Mandil A et al. Knowledge, attitudes and smoking pattern among nursing and laboratory technology students, Dammam, Saudi Arabia. Journal of family and community medicine, 1999, 6(2):51-58.

19. Haddad LG, Malak MZ. Smoking habits and attitudes towards smoking among university students in Jordan. International journal of nursing studies, 2002, 39(8):793-802.

20. Nassar $\mathrm{H}$. The economics of tobacco in Egypt. A new analysis of demand. Health, nutrition and population discussion paper. Washington, DC, International Bank for Reconstruction and Development/World Bank, 2003.

21. Tamim $\mathrm{H}$ et al. Tobacco use by university students, Lebanon, 2001. Society for the

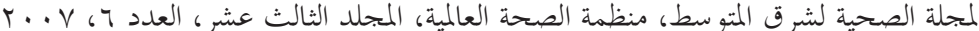


study of addiction to alcohol and other drugs, 2003, 98:933-9.

22. Hamadeh RR. Smoking habits of medical students in Bahrain. Journal of smokingrelated diseases, 1994, 5:189-95.

23 Guidelines for the conduct of tobacco smoking surveys of the general population. Geneva, World Health Organization, 1983.

24 Global Youth Tobacco Survey [website] (http://www.cdc.gov/tobacco/glo-
bal/GYTS/intro.htm, accessed 2 August 2007).

25. No smoking program. Health services. Government.ae [website] (http://www. uae.gov.ae/Government/health.htm, accessed 6 July 2007).

26. Hussain SF, Moid I, Khan JA. Attitudes of Asian medical students towards smoking. Thorax, 1995, 50(9):996-7.

\section{Workshop on the Framework Convention on Tobacco Control imple- mentation and reporting}

The World Health Organization is organizing a workshop on the Framework Convention on Tobacco Control (FCTC) implementation and reporting in Alexandria from 18 to 20 November 2007.

The objectives of the workshop are to:

- discuss the status of the FCTC implementation at the national level;

- start the needed work for reporting;

- take the needed steps to involve other sectors in the reporting mechanism.

Experts from Canada, Djibouti, Egypt, Islamic Republic of Iran, Iraq, Jordan, Lebanon, Libyan Arab Jamahiriya, Oman, Pakistan, Qatar, Saudi Arabia, Sudan, Syrian Arab Republic, Tunisia, United Arab Emirates, and Yemen as well as WHO concerned staff will be participating in this workshop. 